\title{
"Sociological Aspects of Vocational and Technical Education in Urban and Semi-urban Areas in Modern Greece"
}

\author{
Daktilas Eyaggelos \\ University:ntua \\ eleutheriouvelizelou33, perama, Attiki188 63 \\ Greece
}

\begin{abstract}
This paper examines the secondary Technical and Vocational Educationin Greece (TEE) from 1830 until today, through a theoretical review and a quantitative analysis of the data collected with a SPSS program. The aim is to show the level of studies, occupations and interest of EPAL students of Athens, the services offered, the provision of knowledge and vocational rehabilitation. We found out that studentshave origins from low-income families, with parents having a bachelor's degree. They have cultural interests, are politicized and believe that their TEE education will contribute to their professional rehabilitation. Mostly, they are satisfied with the infrastructure, the knowledge they receive and the educators. The theories ofBourdieu, Althusser, Blumer and Tsoukalas are verified. School is a state mechanism that shapes ideology (Althusser), reproduces social inequalities (Bourdieu) and is based in the social interaction (Blumer). Education changed in Greece because of urbanism and clientele (Tsoukalas).
\end{abstract}

Keywords: Vocational and technical education, educational policy,reforms, public education, private initiative, satisfaction, social inequalities, social interaction.

\section{Theoretical Review}

\subsection{Technological and Vocational Education in Greece and Europe, 1830-1930}

In Europe, which was already industrially developed, practical training began in the late 19th century. Leading countries were Germany, England and France. In 1850, in Europe, the issue of providing specialized education and the organization and operation of such schools was already developed as a need for a secondary education that is different from humanities and provides students with professional skills, whether they are already working or not, in order to successfully join the labor market. Germany's new generation of craftsmen, were trained in industrial units and later in workers' cooperatives and educational societies and were also taught History, Geography, Political Economy, Arithmetic, Physics and Geometry. The way of organizing and operating the technical vocational training in these countries was also adopted by Greece, which followed European standards, ignoring in many cases the real needs of

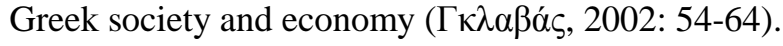

In Greece, since the middle of the 19th century, a substantial concern has been developed for the TEE. The aim was to link education with the economy and to create specialized know-how by adapting education to the rapidly changing needs of society, as well as the student's integration into the labor market. In the 1870s, in the context of European experience, some industrial development began to emerge in Greece, and there was an increasing movement of the

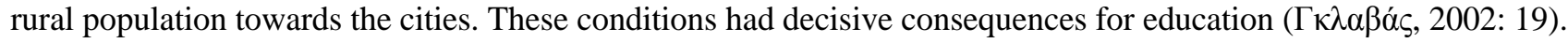

The need for Technological and Vocational education has been the aim of Kapodistrias. From 1829 Kapodistrias had announced the educational program, which intended to carry out and ask for assistance and support from the Nation's representatives ( $\Delta \alpha \sigma \kappa \alpha \lambda \alpha ́ \kappa \eta \varsigma, 1968: 242-243)$. This program included the provision of the necessary resources for the proper education on the Orphanage of Aegina, the strengthening of the schools for the mutual education, the establishment of formal schools for advanced students, the establishment of the "Central War School", the School Hellas, as well as the establishment of a naval school. His program also provided the organization of "higher class" schools for young Greeks, in the form of today's universities, in order to attend those who would become government officials and those who would be involved in science, arts and literature ( $\Sigma i ́ \tau o \zeta, ~ 1978: ~ 53-54)$. But his efforts in organizing did not meet the real needs of the country. A classic example is the Polytechnic, which included few specialties (building, steel, etc.) and did not deal with the problem as a whole. Mostly, the efforts made use of the Fellenberg Industrial School, in favor of mitigating class differences but there was non-response to the real needs of the

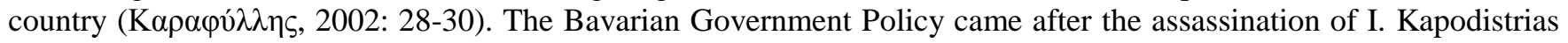
in 1931. 
The governance of the state's affairs was given to the protector forces, who by imposing the absolute monarchy appointed prince Friedrich-Ludwing-Otto as the king of the new Greek state. Because of the young prince's age a threemember council was set up, called Antivasileia( $\Sigma \beta 0 \rho \omega ́ v o \zeta, ~ 2007: 73)$.

This Committee, however, instead of proposing solutions based on the Greek educational reality, faithfully followed

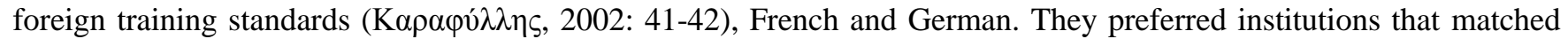

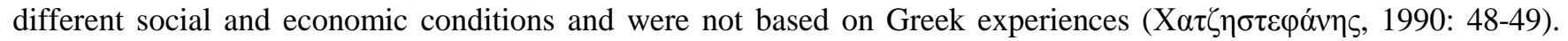
Maurer did not aim to organize Vocational Education, while his only effort in this area was the inclusion of some practical lessons in the training program. Then Zentnergave his idea of creating an Elementary Technical School, an idea that took place in 1837. In the field of secondary education, the type of classical education prevailed (ancient Greek and Latin education). This kind of education was focused on uniformity and monolithicity, as evidenced by the lack of state care to meet the professional needs of Greek society ( $\Delta \varepsilon \rho \beta i ́ \sigma \eta \varsigma, 1985: 41-44)$.In 1870 there was an industrial development which strengthen the intention of Governors to promote the TEE, but there was a resistance of the bourgeoisie.

\subsection{Legislation for TEE on the 19th-20th century}

\subsubsection{Eutaxias Legislation (1899)}

Eutaxias Legislation, by the nameof theMinister of Education, pursued the organization of education on a scientific basis, as well as the introduction of vocational training. In particular, they provided for a mandatory seven-year education, divided into two cycles, four years for the first and elementary education and the three-year course for the transfer of knowledge and skills, with which the students would develop into capable and competent citizens. As stated in the introductory report, Greece as a commercial, native and, above all, agricultural country, should train the future class of workers in their schools by providing them respective knowledge ( $\kappa \kappa \lambda \alpha \beta \alpha$ s, 2000: $185 \& 243$ ). Continuing studies at Gymnasium would enable students to choose between humanitarian and practical directions that contained specific curricula ( $\Gamma \kappa \lambda \alpha \beta \alpha ́$ ک, 2002: 114).

Independent primary education would prepare students for the Gymnasium but also provide them with knowledge that

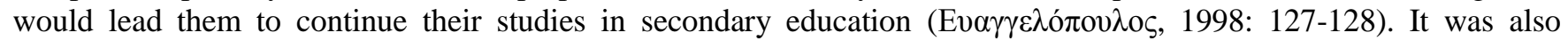
provided basic knowledge of practical and social courses such as agriculture, horticulture, arboriculture, cottongrowing, beekeeping, marketing, data on the rights and duties of the constitutional citizen, as well as elementary

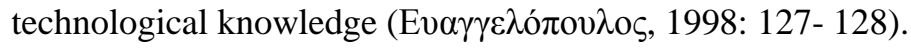

Although Eytaxias legislation were the first scientific contribution for the educational matters and would have brought significant changes in the organization of education, they had aroused reactions. So the parliament voted against them. Also, the change in the structure of education, which would be "expensive" and would burden the state budget

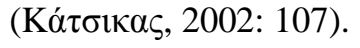

\subsubsection{Venizelos Legislation (1913)}

The introductory report of Venizelos Legislation, by the name of the minister of Greece,was submitted to Parliament by Education Minister IoannisTsirimokos, after his collaboration with Glinos. The aim is to adapt the education system to

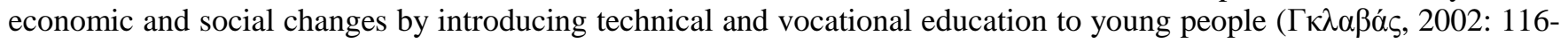
117).

According to Tsimirokos's introductory the reforms included "to organize the education through the cultivation of general skills and the provision of appropriate knowledge for special schools or for the technical professions."

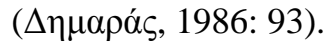

In particular, the beginning of the 20th century marks a new era, expressed mainly through the new political, economic and social ideology of Venizelos. Important projects were the Volos School with innovative applications, the

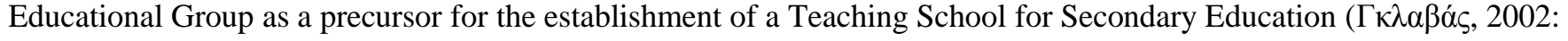
116).Two types of schools were established in Secondary Education: the six-year High School and the "Urban Schools". The Gymnasium was preparing future scientists, wholesalers and big industrialists, since it was addressed to the "upper class", while "Urban Schools" were destined for future traders and microbrewers. The Urban schools were also for women, which taught cutting, sewing, cooking, infant care and also History, Geography, Physics and Chemistry, Home Economics, Hygiene, Nursing, Music, Gymnastics and Greek Dances. In addition, to Urban Schools, children's education was complemented by night or Sunday schools and the lower Educational Schools ( $\Gamma \kappa \lambda \alpha \beta \alpha$, 2002: 116-119). The graduates of Urban Schools were absorbed, after examinations, at the Primary School Teaching School, at the Navimon School, as well as in commercial and vocational schools. For the graduates of the Primary Schools they were provided an attendance of supplementary courses with the instigation of the employers

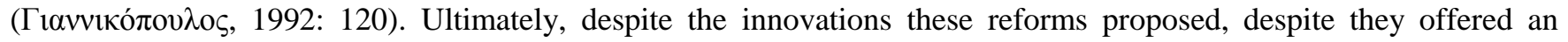


education due to the modern tendencies and ideas and despite turning to more practical vocational education, there were not voted because of the reaction of some groups, such as philologists, teachers of secondary education and

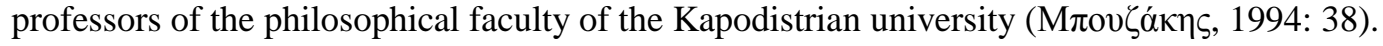

In addition, the demands for more practical studies were inconsistent with the actual assessment of social and economic data, nor with the corresponding trends in the European area. There was also a lack of practical guidance of graduates and their professional qualifications, monolithicity in the education system as it survived the Bavarian era, lack of schools, authoritarian administration, undergraduate teacher training and other logistical shortcomings. What has been mentioned above rendered the educational work ineffective and unrealizable on the preparation of children for life

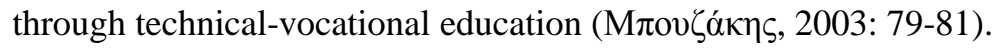

\subsubsection{Government reforms of Venizelos, Thessaloniki 1917}

The reforms of 1917 aim to adapt the education system to the needs of economic development, which means that pupils should receive the necessary resources for life from the education system (A $\theta \alpha v \alpha \sigma o v ́ \lambda \alpha-P \varepsilon ́ \pi \pi \alpha, 1999: 52)$. The spoken daily language (Dimotiki) was established to the Primary studies and the system of writing books was reformed, but the reforms did not impose "Urban Schools". The aim of the reform was the access to the education sector across all

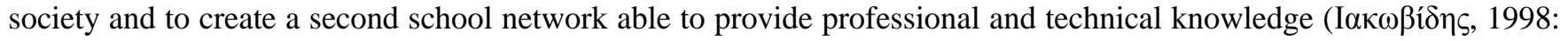
103-105). So, this reform constituted a proposal-repercussion of the democratic institutions of the twentieth century. The aim was to adapt to the new social and economic conditions, after the occupation of power by the bourgeoisie, which was protected by E. Venizelos. The aim was to serve socio-economic changes through the reform of education

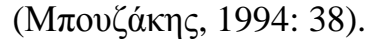

\subsubsection{The Reform of 1929}

The 1929 reform aimed at adapting the school to modern needs and creating conditions for the social and economic

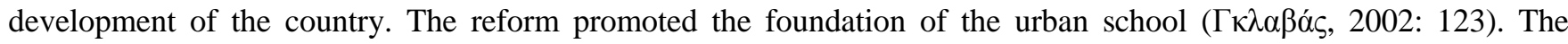
elementary education of Greek children was preferred. It includes kindergartens, elementary schools and lower technical and vocational education. The purpose of the operation of the lower vocational schools was to pass on practical knowledge to young people, to prepare properly for the trades and craft trades, and to strengthen households for girls. Concerning secondary education, the ultimate goal of education was the scientific preparation of those who would continue higher education, as well as the existence of proper citizens who would have a general education. The latter was considered necessary for their social life (I $\alpha \kappa \omega \beta i ́ \delta \eta \varsigma, 1998: 112$ ).

There was an establishment and organization of vocational schools, which concerned the vocational training of elementary school graduates in vocational schools, such as commercial, agricultural, craft and girls' schools. These

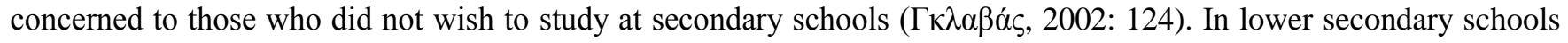
they could study those who had received a baccalaureate from the six-grade elementary school. Their attendance was two or three years old and their main aim was to regulate the problem of overcrowding and to integrate some of the pupils into the labor market from the age of fourteen. But, the technical-vocational training was not fully succeeded, despite the expectations. An exception is the operation of some new technical schools, such as the Sivitanidio School of

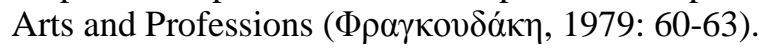

In, the period in which we look at, it appeared a differentiation between intellectual and practical functioning and activity, producing in a similar way a rigidly positioned value system with negative value on the choice especially for professional lessons. In this way, inequalities dominated, which also appear in other social activities, such as in the profession, forming different types of education, unequal among themselves. In fact, the idea that determined the implementation of the 1929 reform was the attempt to solve the hypertrophy of the students of the gymnasiums and to

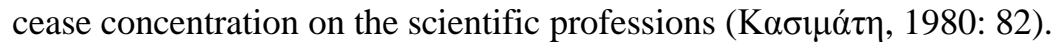

\subsection{History of TEE schools}

The first schools that existed during the Ottoman rule were those within the monasteries. Since the mid-16th century craft centers and apprenticeship schools have been developed (metalworking, hagiography, weaving, shipbuilding, etc.). after Kapodistrias there were created charitable associations, such as the Orphanage of Aegina, EfevioAveroff, Hantzi-Konsta, who were training young people technically. There were also self-teaching schools (elder students teaching younger) that divided into three-year crafts and School Templates (who preparated for studies abroad). Some Agricultural Schools were the Farmhouse of Tiryns (Kapodistrias) and the Agricultural Schools for Men from 1880 and early 20th and Schools for Women. But, there were unpopular beyond the students and not well organized ( $\Gamma \kappa \lambda \alpha \beta \alpha \dot{\varsigma}$, 2002·Sitos, $1978 \cdot$ Kov́кov, 1989). 
From the Business Schools we mention the Commercial School (1900), the Municipal Commercial School (1901) and the Higher School of Commercial Studies (now ASOEE, 1920). Until 1931 there were 49 secondary and lower commercial schools under private law. From 1855, the Antoniadou Commercial School in Syros (1855), the Commercial School of Samos and others were operating privately. The Roussopoulos Academy was the most important in the city of Athens (it had a pre-school and six schools).

Also, from 1867 there were naval schools in Syros, Hydra, Galaxidi, Argostoli. The School of Engineering of the Piraeus Association (1895) and the Night School of Naval Engineers of the Educational Association "Prometheus" (1900) were individually operated. As for the Professional girls training, from the 19th-century there were schools such as Parnell, the Amalio Orphanage, etc., for cooking, sewing, moral and reading, writing and arithmetic. They operated without state support and provided education beyond primary and teacher training (egArsakis Teacher / Teacher of

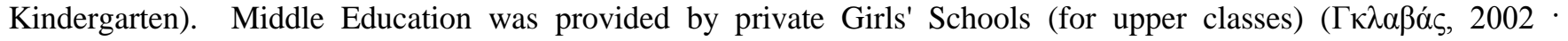

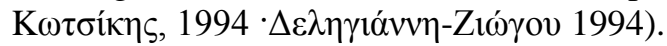

Some of the Higher Technical Schools are Aegina Orphanage \& Military School, which provided technical knowledge, the Mechanical Workshop led to the School of Building, Polytechnic (1836), the Polytechnic School (1837). It was in the beginning a Sunday school and from School of Arts became superior (MetsovioPolytechneio). From the Secondary and Lower Technical Education, we mention that factories operate as training schools, Socrates of Piraeus or Pericles that trained craftsmen, The Hellenic Craft Society (1892) that teaches Engineering, Jewelery, BEA Rousopoulos that provides practical training to industrialists, traders, cheese makers and others. Significant are the Sebatianides,

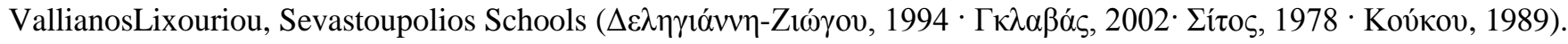

\section{Technical and Vocational education in Greece, 1930 until today}

\subsection{The TEE in Metaxa dictatorship}

IntheMetaxa dictatorship in 1936, the laws indicate that decisions and actions were taken without the consent of anyone

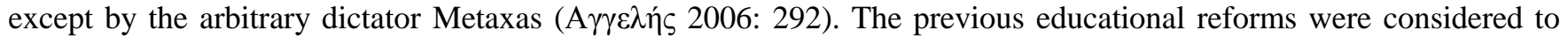
promote communism so the young people were encouraged to engage in agricultural work in the countryside. Unlike previous educational reforms, the new ones provided a theoretical background for students to receive some vocational training and then rehabilitation (A $\gamma \gamma \varepsilon \lambda \eta ́ \varsigma, ~ 2006: 214-215)$, but in Secondary vocational education only eleven thousand students were studying, while the content was fascist. In fact, vocational training has not been established and its quality has been extremely low, (Kó $\sigma \tau \kappa \alpha \varsigma, 2007: 169-175)$. Some Urban Schools were established with four directions: Housekeeping, Agriculture, Merchant and Industrial, but was targeted mainly at boys from high social classes, as well

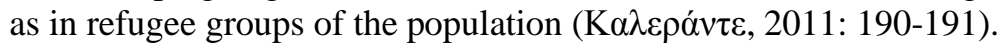

\subsection{The reform of 1959}

After the World War II vocational training had been developed from the public, under the supervision of the Ministry

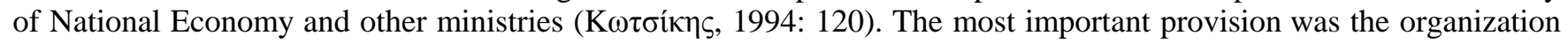
of secondary vocational education and training in the country. The mechanics schools in Athens and Thessaloniki,

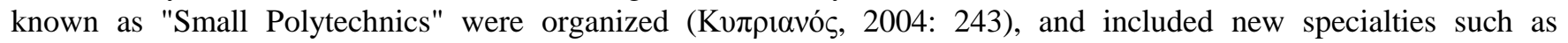
construction, industrial production, mining electronics, telecommunications, naval engineers, surveying engineers

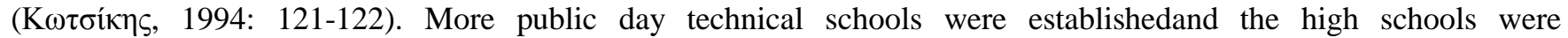
distinguished in technical, rural, economic, nautical and foreign languages, while urban schools became vocational schools. The 1959 Legislative created lower vocational schools, of one to four years' duration and suitable for young farmers interested in technical knowledge. The study program included general knowledge courses. Pedagogical

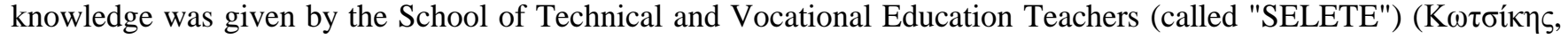
1994: 123, 243).

\subsection{The reform of 1964}

The reform of 1964 with minister Papandreou aimed a democratic organization of society, social equality and humanity, in order to bring prosperity to the social ensemble ( $\Delta \eta \mu \alpha \rho \alpha ́ s, 1995: 475-490)$. The TEE would contribute to

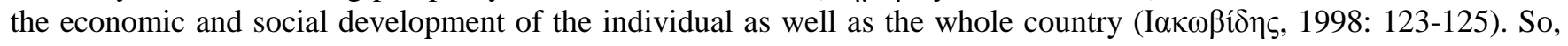
Law 4379/1964 increased the duration of compulsory education. The training programs were modified and new courses were introduced and more technical and vocational education schools were set up, which did not require entrance examinations. At the same time, they maintain economic and naval high schools and the Zanneios technical

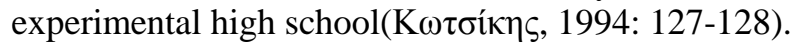

\subsection{The reform of 1976-77}


With this reform there was an establishment of Technical Vocational Schools and Technical Vocational Lyceums (equivalent to General Lyceums / admission with high school diploma and Panellinius right-exams after highschool for entrance in universities).

The Technical Vocational Lyceums emerged from the abolition of the Technical School of Technology

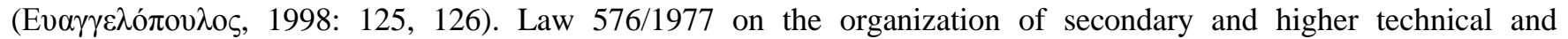
vocational education separated technological and vocational training into middle and upper. This means that those who graduated from high school were offered the option of three years general or technical vocational training.

They also had the option of attending high school, after entrance examinations. But reality showed that those who were unable to enter the General Lyceum chose technical-vocational training. Important were the night schools, for trainees over 17 years old (Ká $\sigma \sigma 1 \kappa \alpha \varsigma, 2007: 229)$.

\subsection{The reform of 1981-1989}

The secondary education technical vocational schools in Law 1232/1982 lasted from 1 to 2 years, aiming at practicing the students in the specialties chosen at their entry. There were workshops for the technical and professional specialties.

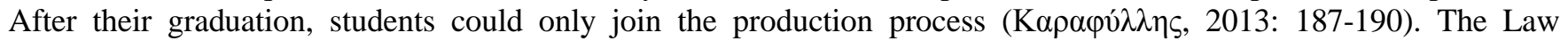
$1566 / 85$ proposed the integration of general education with technical education as well as the creation of multidisciplinary Lyceums (I $\alpha \kappa \omega \beta i \delta \eta \varsigma, 1998: 35$ ). The Technical-Professional Lyceum was designed to give the students the necessary techniques or other professional knowledge and to develop their skills so that after their graduation they can work on technical fields. At the same time, the Unified Multi-Class Lyceums linked general and technical vocational education and responded to the prevailing educational, economic and geographic conditions.

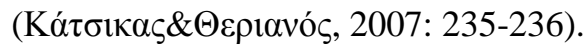

\subsection{The reform from 1992 until today}

Law 2009 / 14-2-92 provided the establishment of the Organization for Vocational Education and Training (OEEK) in order to operate the Vocational Training Institutes (IEK), in which they were able to study graduates of a single

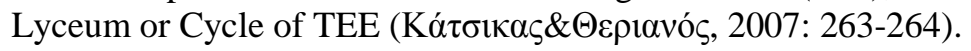

On 1996 great emphasis was placed on the "neglected" technical and vocational training. Initially the concern was the logistical infrastructure and the recruitment of qualified teaching staff, initiatives that appeared to be crucial,

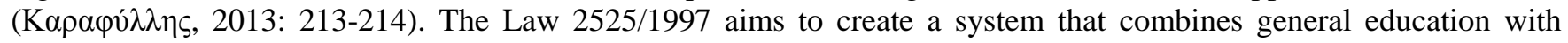
specialized technical and professional knowledge and there were two cycles: A and B, including fields and specializations. Graduates of the First Cycle could obtain a license to pursue a profession, continue their studies in the B-course of TEE. They could still enroll in the Secondary Lyceum class B if they wished or could obtain a license to practice, enroll in Vocational Training Institutes, IEKs and in corresponding specialties in order to acquire the postsecondary vocational training. The Law 2643/1998 increased theoretical and laboratory courses for each specialty. In each course there was a specific curriculum. The laboratory equipment also increased. In the 2002-2003 school year,

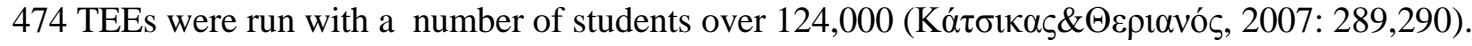

The Law 3191/2003 also concerned secondary vocational education and training which provided from the Association of Vocational Training with Employment (ESSEEKA). The objectives were to meet needs in the labor market, provided for the professional and social integration of graduates who would acquire professional qualifications and advancement as well as social recognition from the graduation of vocational and technical schools. The Law 3475/2006 aims at the coexistence of general education with technical professional knowledge. The ultimate aim was: "to develop students 'skills, initiative, creativity and students' thinking," (b) to transmit the required technical and professional knowledge and to develop their relevant skills, (c) to provide students with the necessary knowledge and supplies to continue their studies at the next level of education ". With this Law the Technical Vocational Schools were abolished and the vocational training provided by the Professional Lyceums (EPAL) and Vocational Schools (EPAS)

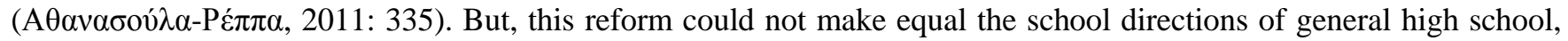
vocational lyceums and vocational schools. Generally, TEE problems are: the lack of materials and infrastructure in order to meet the educational needs, the lack of public spending, the development of extracurricular network, school

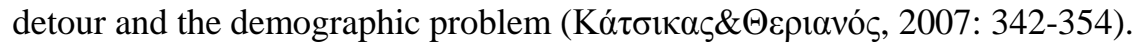

\section{The theories of Pierre Bourdieu, Herbert Blumer, Althusser Louis, and Constantine Tsoukalas for education}

\subsection{Theorie of Pierre Bourdieu}

According to Bourdieu "habitus" is shaped by the social background and constructs the microstructure of society. Education as a micro-level is understood and having dialogue with society as a macro-level, as well as socio-economic, cultural, racial, physical inequalities that education can reproduce. The goal is to reduce inequalities in education and 
acquire knowledge to improve the social status of children. Also, skills and attitudes and cultural capital, come from the

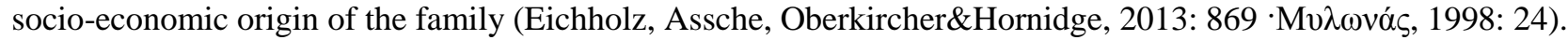

The concept of practice, between habitus and field, is socially sanctified ways or "social habitus". It can be formally instituted as a law that will urge or prohibit. The strategy is the unmistakable, reflective feeling of our position within a field, it involves subjective aspirations.Iit is the effortless manifestation of a habitus, a social instinct (Grenfell \& James, 1998: 59-63).

\subsection{Theorie of Althusser}

According toAlthusser Ideology has no history in a analytical sense. It is a phenomenon that always exists in human societies and shows the relationship that people create between them, based on the conditions of their existence. Ideology emerges through the Ideological Mechanisms of the State (religious, school, family, legal, political, cultural, media) and is consolidated through the subjects that act and the school environment adopted by the capital of the dominant groups. If a relationship is represented in ideology, it is always fantastic, that is, ideology is a shift of reality into fantastic. "Ideas" do not come from "themselves" but from the practices in which each person is involved. Each

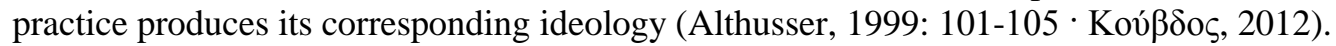

\subsection{Theorie of Blumer}

According to Blumer the idea of Symbolic Interaction is a dominant concept.By this is meant that individuals operate in accordance with the assumption of roles of other members of society. People act on things according to the importance they have for them. But, the meaning of the objects stems from the course of social interaction. The meanings actually are modified through an interpretative process that involves self-reflection and interaction between individuals. The result of that is that people experience the world as a constructed reality (for example people are

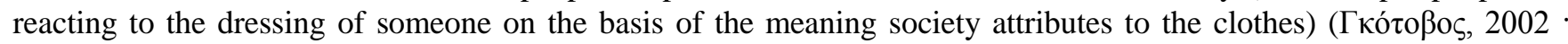
Hewitt kal Shulman, 2011).

\subsection{Theorie of Tsoukalas}

According to Tsoukalas, Greece in the late 19th century had a hypertrophic urban population. The result was that for every active employee, there was one candidate that wanted to gain the same job. At the beginning of the 20th century conditions lead to more systematic attempts to change the education system. There was over-education and illiteracy,

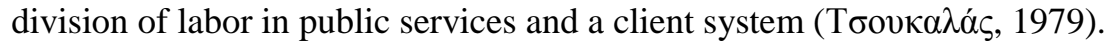

Based on his empirical material Tsoykalas concludes that "historical search can only be holistic, as events, institutions, behaviors and social values are continually mutually reinforcing and interacting."The role of education is sovereign, while its basic characteristics are that is free and has a one-dimensional character, which prioritizes pupils from the primary to the highest grades. He concluded that Greece' s education is early "democratic" as a system, compared to those of the capitalist countries. In addition, the choice of secondary education was the starting point of social mobility, from a rural environment to a middle-class social environment, where technical and scientific knowledge would prevail

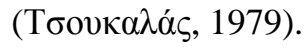

\section{Methodology of the research}

This essay used the Quantitative Approach which will contribute to understanding and familiarity about what should be observed and measured. Quantitative research will use sampling. The purpose of quantitative analysis is to discover through objective measurement and numerical analysis the magnitude and not the reasons for the hypothesis formulated through the research questions. Thus, through numerical data, we will try to verify the research questions on the chosen case in order to understand the magnitude of social reality at a generalized level (Cohen, Manion \& Morrison, 2011).

Research Tool: Closed Structured Questionnaire. This method allowed us to survey a large (representative) population with strict and valid control.

Reliability-validity:

1) Compatibility of purpose, methodological approach, research tool, sample

2) Statistical analysis of data, using the SPSS program, frequencies.

Sample: 917 EPAL Students of Athens, in particular EPAL school of the areas Perama, Zografou, Eleysina. Samplingtechnique: Samplingsurvey.

\section{Results of the research}

According to demographic characteristics such as studies, age, gender, home address etc, we found out that:

1) Almost all students do not have any additional degrees (except for $1.6 \%$ of respondents) (Appendix 1).

2) According to gender, there is a predominance of pupils boys with $62.5 \%$, compared with $37.5 \%$ of women. So, about the two-thirds of EPAL students are boys (Appendix 2). 
3) According to pupils' age, $91.5 \%$ of respondents (839 persons) are aged between 15 and 18 years. Only 68 students $(7.4 \%)$ are aged $19-25$ and only 10 are over 25 years of age.

4) According to class, $50.7 \%$ of the sample were pupils of the $2^{\text {nd }}$ class of Lyceum. A smaller number of pupils attend the last grade of EPAL and a much lower number of students is in the first grade (19\% of the total) (Appendix 3).

5) Area of the school is 3 different lyceums (Perama, Zografou, Elefsina). The number of pupils does not differ substantially, and of the three schools the sample was about 300 pupils (33).

6) According to specialties selected by students, engineer, electrician and nurse are prevailing, with $25.7 \%, 16 \%$ and $15.4 \%$, respectively. To a lesser extent, students choose the specialties of refrigerant and engineer merchant navy. The rest specialties are $30.8 \%$, corresponding to 282 students (Appendix 4).

7) Most of the students and their families lived in Athens $(95,2 \%)$.

8) EPAL pupils studied in Primary and Secondary school in a public school (98\%).

9) According to family income, most EPAL students come from families with an income of up to $€ 10,000$, at $61.7 \%$, while $32 \%$ of respondents come from more wealthy families, with an income of between 10 and 20 thousand euros. Children with a family income of more than $€ 20000$ are a minority (6.3\%) (Appendix 5).

10) According to Father's education level, almost half of the students $(49.4 \%)$ are children whose father has completed secondary education. 24.4\% said their father had completed high school. TEI or University degree have only the 9,7\% of the fathers (Appendix 6).

11) According to mother's education level, the percentages are familiar to fathers education level (Appendix 7).

According to the experience background of students of EPAL we found out the following:

1) Pre-existing experience in technical constructions. It has been found that the majority of children (78.7\%) have not dealt with the subject of their specialty before starting to attend EPAL. So the knowledge and the experience they acquire in them are new skills and abilities.

2) Regarding to the preferences of music, the majority of $44.7 \%$, distinguish pop and rock as their preferred music, while a significant but lower percentage of $27.5 \%$ prefer the popular and the heavy folk song. To a lesser extent, students choose artistic, classical or other kinds of music.

3) Concerning EPAL students' interest in cultural education, more than half of the students (53\%) have visited a museum more than three times, while $44,6 \%$ have visited a museum from one to three times . Less is the percentage of children who have attended even one concert of classical music (17.7\% of the total sample) (Appendix 8).

4) EPAL students use poems as a means of expression (13.4\% of EPAL students), while $22.2 \%$ of them state that they have resorted 1 to 3 times in poetry composition in order to express themselves.

5) According to the politicization of the EPAL students, it was found that 52.3\% said they had knowledge of the prevailing situation in politics, while $47.5 \%$ were not politicized. Regarding whether or not students support a party only $16.4 \%$ said they were in favor of a particular political party (Appendix 9).

6)Regarding the contact of EPAL students with art, $60 \%$ have no visit acontemporary art galleries, while only $3.4 \%$ have made more visits to galleries (more than three).

7. For the factors that have the greatest power for the survival of the individual, $23.2 \%$ of the majority of the students consider that money has the greatest influence and power. Work follows with $18.1 \%$ and the power of ideas and technology with $13.1 \%$ and $11.7 \%$ (Appendix 10).

According to the evaluation of the effectiveness of the EPAL study and its contribution to the acquisition of knowledge and the career path, we found out that:

1) EPAL's contribution to professional rehabilitation is high and positive by $82,1 \%$ of students.

2) The contribution of laboratory courses to the acquisition of technical knowledge and professional rehabilitation is positive by $88.5 \%$ of students.

3) The contribution of technical courses to understanding the operation of machines is judged positive by $86.7 \%$.

4) Familiarization with machines and technical constructions is high (55.8\%).

According to Knowledge level of the EPAL students, we find out that:

1) For parts of the fraction, $84.6 \%$ of the students responded correctly.

2) For the electromagnetic field, pressure and volume ratio, temperature, which are laws of physics, the majority responds correctly with $93.7 \%, 86.7 \%$ and $82.1 \%$, respectively (Appendix 11).

3) For the law of substance impurity, $39.1 \%$ responded wrongly.

4) For the parts of a proposal (verb, subject, accused), $81.56 \%$ of students responded correctly.

5) For the question who took the Nobel price only $42.2 \%$ gave the right answer.

According to the satisfaction of students from the halls, the infrastructure, the workshops, the teachers, the activities, we found that: 
1)56.9\% of EPAL students consider the classrooms and school infrastructure to be unsatisfactory or very poor, while $20 \%$ declare a high level of satisfaction.

2)For the laboratories' infrastructures $26.4 \%$ and $26.6 \%$ reported moderate and high level of satisfaction, while $17.2 \%$ of the respondents stated the highest degree (Appendix 12).

3) For satisfaction with extra-curricular activities, $45.7 \%$ of the pupils declare not at all satisfied.

4) For the satisfaction from teachers, most of the students said they were quite satisfied with the image of the teachers, but there is also a figure of $34.6 \%$, which corresponds to the pupils who have no or very little satisfaction.

According to the correlation and influence of the demographic characteristics on students perceptions: Older age affects the degree of satisfaction on building and laboratory infrastructures, extradural activities and the teaching staff. Students over the age of 25 show almost double rate of satisfaction, compared to younger students. Older students identify more problems in the EPAL infrastructure, extra-curricular activities and teacher performance.

According to how the course program affects professional rehabilitation of students, and if this is significantly related to their satisfaction with infrastructure and teaching staff:

1) $28 \%$ think that the course schedule will not help in their professional rehabilitation and is related to the lowest level of satisfaction, especially the laboratory infrastructure and teaching staff, but the extra-curricular activities do not affect their point of view.

According to the verification of the theories, it was found that all three schools verified Bourdie's theory at a fairly significant rate (48,41\% Perama EPAL, 55,12\% EPAL Zografou, 63,33 EPAL Elefsina). The Blumer, Althusser (less than $25 \%$ ) and Tsoukalas (less than $3 \%$ ) theory are verified by a lower percentage, not exceeding $28 \%$.

\section{Conclusions}

The development of technical and vocational education in Greece began in the late 19th century, following the goals of the other economically developed European states. The modern Greek state was delayed in its economy and its stereotypical perceptions delayed the development of the TEE.

Secondly, while no strategies for technical and vocational training had been adopted, serious reform efforts were made in 1959 and matured from 1977 onwards, but many of the changes by the subsequent governments, created confusion and insecurity.

A serious problem is that there was no connection between the TEE and the labor market and the economy, nor a practical work on employment places. Even today, the infrastructure and human resources problems faced by EPALs demonstrate the need for reform and change.

From the empirical data we understood that pupils' demographics are: mainly males, not possessing any extra diploma, from low-income families and parents who hold a bachelor's degree. Most of the students have cultural interests and therefore cultivation and are politicized, but they do not support a political party. They mostly have a good level of knowledge.

Most students believe that their education will contribute to their professional rehabilitation due to courses and workshops. EPAL students are satisfied with the infrastructure, the knowledge they receive and the educators. Student's views on the influence of lessons and the teaching program on finding a job are not independent of the degree to which they are happy with their learning conditions. However, their satisfaction with extracurricular activities is independent of any opinion they suggest about the contribution of EPALs to their professional rehabilitation.

The theories of the philosophers Bourdie, Althusser, Blumer and Tsoukalas are verified, with Bourdie's precedence about reproduction of social inequalities to precede . In a smaller percentage, Blumer's theory is verified, meaning that there is a social interaction that makes sense to the things people act for. Less than $25 \%$ is the verification of Althusser's theory, so school is a state mechanism that shapes ideology. The 3\% verification rate of Tsoukalas' theory shows that urbanism and the growth of the clientele led to changes in the educational system.

It is necessary to reorganize the Technical and Vocational Education, although the pupils' image seems positive in terms of how EPAL operate, so that EPAL could provide more opportunities, options and possibilities. The reorganization must follow the needs of the economy and market.

\section{References}

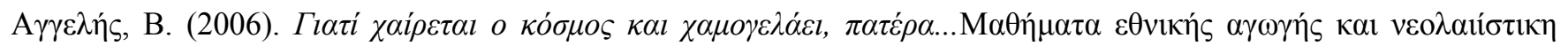

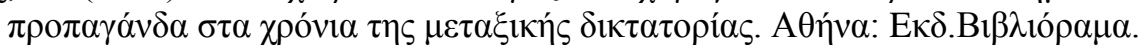




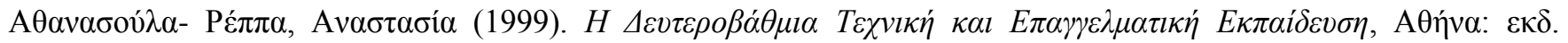
'E $\lambda \lambda \eta \nu$.

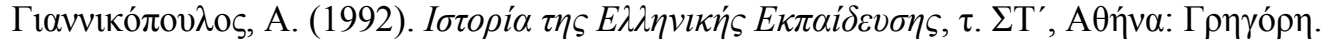

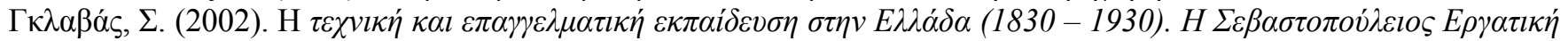

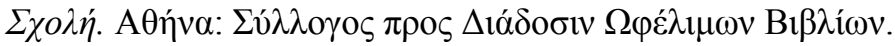

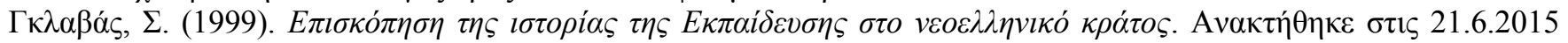

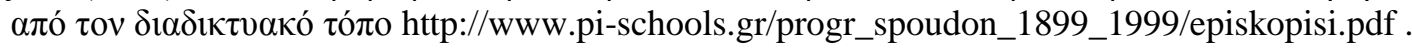

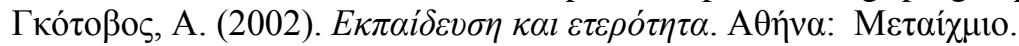

Cohen, L., Manion, L. \& Morrison, K. R. B., (2011). Research methods in education. Oxon, UK: Routledge.

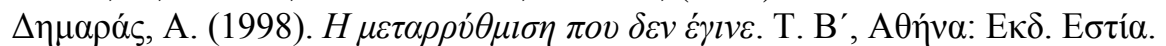

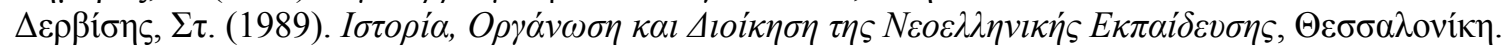

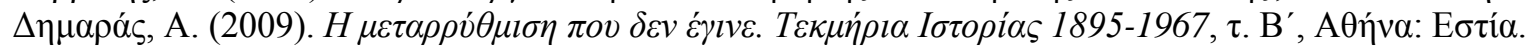

Eichholz, M., Van Assche, K., Oberkircher, L. \&Hornidge, A. (2013). Trading Capitals? - Bourdieu, Land and Water in rural Uzbekistan. Journal of Environmental Planning and Management, Volume 56, Issue 6.

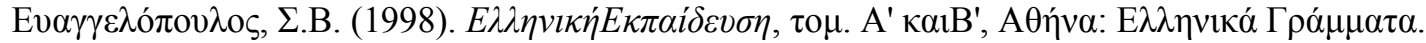

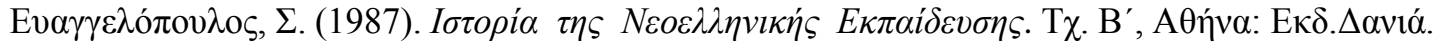

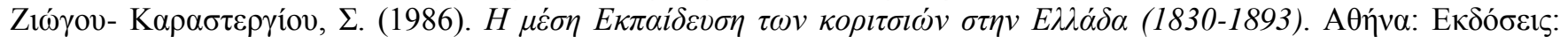

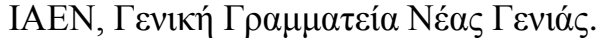

Grenfell, M. \& James, D. (1998).Bourdieu and Education. London: Falmer Press.

Hewitt, J. P., \& Shulman, D. (2011). Self and society: A symbolic interactionist social psychology. Don Mills, ON: Pearson.

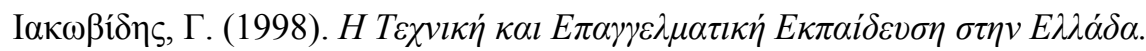

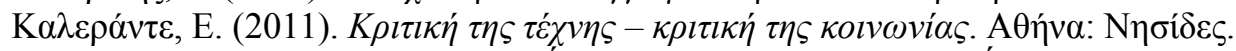

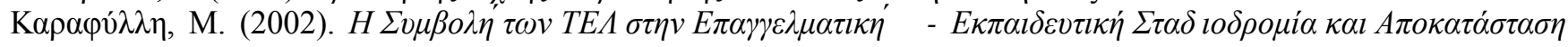
$\tau \omega v N \varepsilon \dot{\varepsilon} \omega v, \tau \mathrm{O} \mu .3$.

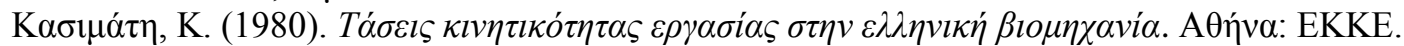

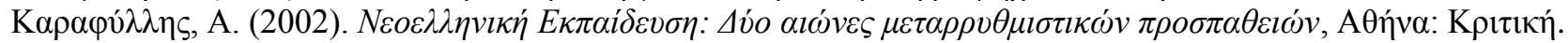

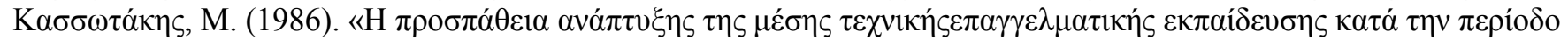

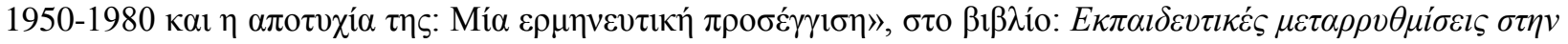

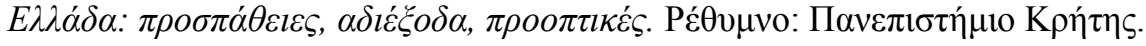

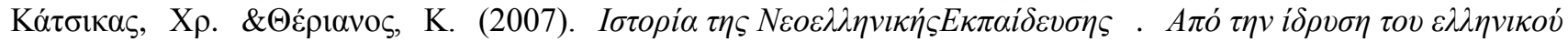

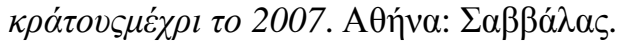

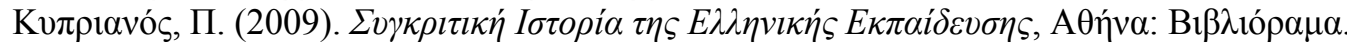

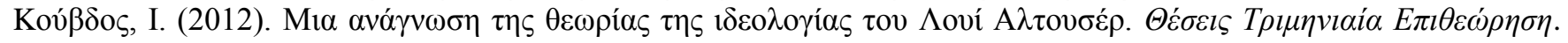

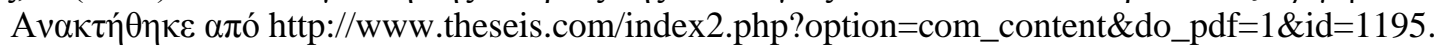

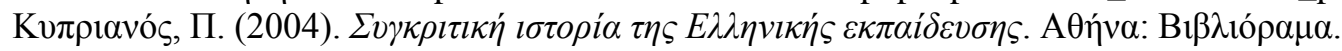

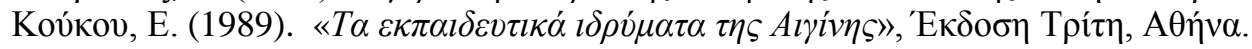

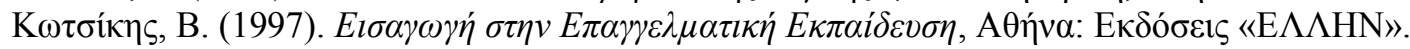

К 'E $\lambda \lambda \eta \nu$.

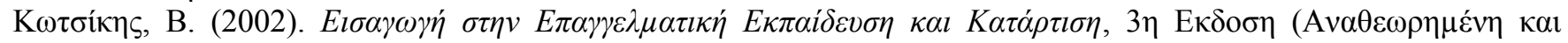
$\Sigma v \mu \pi \lambda \eta \rho \omega \mu \varepsilon ́ v \eta)$. A $\theta \eta \dot{v \alpha: ~ E \kappa \delta o ́ \sigma \varepsilon เ \varsigma ~ « E \Lambda \Lambda H N » . ~}$

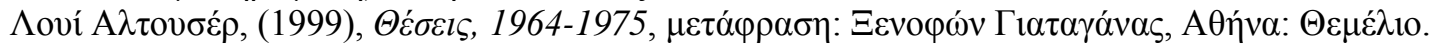

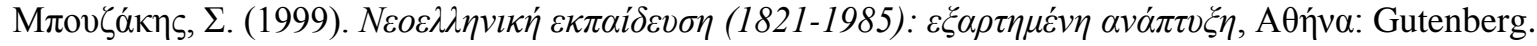

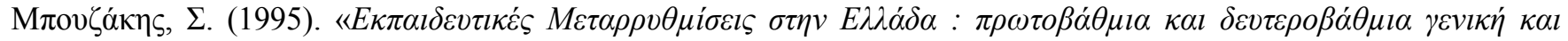

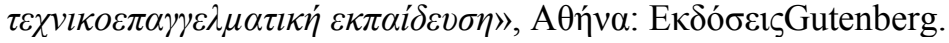

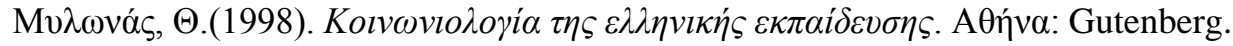

М

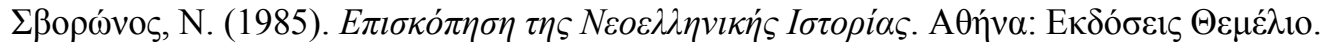

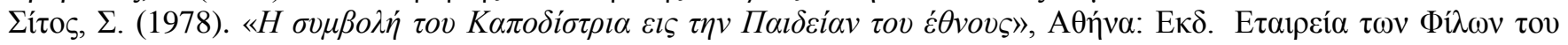

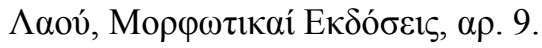

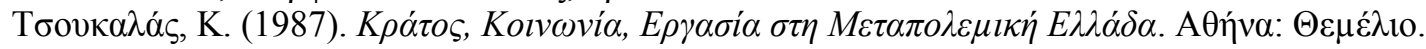

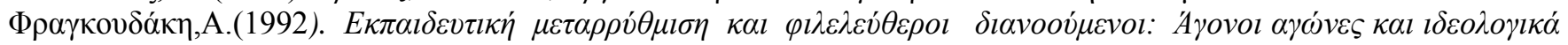

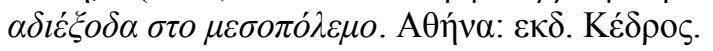

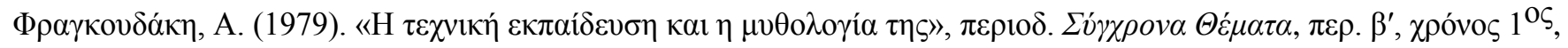
$\tau \varepsilon v ́ \chi .4$. 


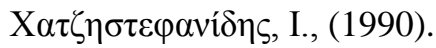

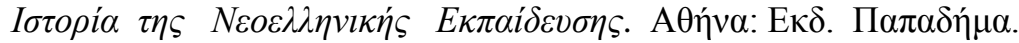

\section{Appendixes}

APPENDIX 1: Frequencies related to the possession of another qualification

\begin{tabular}{|c|c|c|c|c|}
\hline \multicolumn{5}{|c|}{ Do you have another degree? } \\
\hline & Frequency & Percent & Valid percent & Total Percentage \\
\hline GEL & 5 & 0,5 & 0,5 & 0,5 \\
\hline EPAI & 8 & 0,9 & 0,9 & 1,4 \\
\hline ANO & & 0,2 & 0,2 & 1,6 \\
\hline NO & 902 & 98,4 & 98,4 & 100,0 \\
\hline Total & 917 & 100,0 & 100,0 & \\
\hline
\end{tabular}

APPENDIX 2: Frequencies based on the gender of the students

\begin{tabular}{|c|c|c|c|c|}
\hline \multicolumn{5}{|l|}{ Gender } \\
\hline & Frequency & Percent & Valid percent & Total percent \\
\hline WOMAN & 344 & 37,5 & 37,5 & 37,5 \\
\hline MAN & 573 & 62,5 & 62,5 & 100,0 \\
\hline TOTAL & 917 & 100,0 & 100,0 & \\
\hline
\end{tabular}

APPENDIX 3: Frequencies based on the classroom of the students

\begin{tabular}{cllll}
\hline What is your class? & & & \\
\hline & Frequency & Percent & Valid Percent & Total Percent \\
\hline A' Grade of Lykeio 176 & 19,2 & 19,2 & 19,2 \\
B' Grade of Lykeio 465 & 50,7 & 50,7 & 69,9 \\
$\Gamma^{\prime}$ Grade of Lykeio 276 & 30,1 & 30,1 & 100,0 \\
Total & 917 & 100,0 & 100,0 & \\
\hline \hline
\end{tabular}

APPENDIX 4:Frequencies based on pupils' specialties

\begin{tabular}{lllll}
\hline \hline What specialty have you chosen? & & & & \\
\hline & Frequency & Percent & Valid Percent & Total Percent \\
\hline REFRIGERANT & 75 & 8,2 & 8,2 & 8,2 \\
ELECTROLOGY & 147 & 16,0 & 16,0 & 24,2 \\
MECHANICS & 236 & 25,7 & 25,7 & 49,9 \\
MECHANICS of Navy & and36 & 3,9 & 3,9 & 53,9 \\
Polytexneio & & & & \\
NURSE & 141 & 15,4 & 15,4 & 69,2 \\
OTHER & 282 & 30,8 & 30,8 & 100,0 \\
Total & 917 & 100,0 & 100,0 & \\
\hline \hline
\end{tabular}

APPENDIX 5:Frequencies based on the level of family income

\begin{tabular}{lllll}
\hline \hline What is your family income? & & & & \\
\hline & Frequency & Percent & Valid Percent & Total Percent \\
\hline Up to $10.000 €$ & 566 & 61,7 & 61,7 & 61,7 \\
From $10.001 €$ to $20.000 €$ & 293 & 32,0 & 32,0 & 93,7 \\
$20.001 €$ and more & 58 & 6,3 & 6,3 & 100,0 \\
Total & 917 & 100,0 & 100,0 & \\
\hline \hline
\end{tabular}


APPENDIX 6: Frequencies based on the father's level of study

\begin{tabular}{|c|c|c|c|c|}
\hline \multicolumn{5}{|c|}{ What is your fathers study level? } \\
\hline & Frequency & Percent & Valid Percent & Total Percent \\
\hline NO SCHOOL & 21 & 2,3 & 2,3 & 2,3 \\
\hline PRIMARY SCHOO & L130 & 14,2 & 14,2 & 16,5 \\
\hline HIGH SCHOOL & 224 & 24,4 & 24,4 & 40,9 \\
\hline LIKEIO & 453 & 49,4 & 49,4 & 90,3 \\
\hline UNIVERSITY/TEI & 89 & 9,7 & 9,7 & 100,0 \\
\hline Total & 917 & 100,0 & 100,0 & \\
\hline
\end{tabular}

APPENDIX 7: Frequencies based on the mother's level of study

What is your mother's study level?

\begin{tabular}{lllll}
\hline & Frequency & Percent & Valid Percent & Total Percent \\
\hline NO SCHOOL & 12 & 1,3 & 1,3 & 1,3 \\
PRIMARY SCHOOL109 & 11,9 & 11,9 & 13,2 \\
HIGH SCHOOL & 253 & 27,6 & 27,6 & 40,8 \\
LIKEIO & 455 & 49,6 & 49,6 & 90,4 \\
UNIVERSITY/TEI & 88 & 9,6 & 9,6 & 100,0 \\
Total & 917 & 100,0 & 100,0 & \\
\hline \hline
\end{tabular}

APPENDIX 8: Frequencies based on visits on archaeological museum

\begin{tabular}{lllll}
\hline \hline How many times have you visited a museum? & & \\
\hline & Frequency & Percent & Valid Percent & $\begin{array}{l}\text { Cumulative } \\
\text { Percent }\end{array}$ \\
\hline NEVER & 27 & 2,9 & 2,9 & 2,9 \\
1-3 TIMES & 404 & 44,1 & 44,1 & 47,0 \\
MORE & 486 & 53,0 & 53,0 & 100,0 \\
Total & 917 & 100,0 & 100,0 & \\
\hline \hline
\end{tabular}

APPENDIX 9: Frequencies based on whether or not students support a particular political party DO you support a political party?

\begin{tabular}{lllll}
\hline & Frequency & percent & Valid Percent & Total Percent \\
\hline YES & 150 & 16,4 & 16,4 & 16,4 \\
NO & 767 & 83,6 & 83,6 & 100,0 \\
Total & 917 & 100,0 & 100,0 & \\
\hline \hline
\end{tabular}

APPENDIX 10: Frequencies about the factor that holds the greatest strength according to EPAL students Do you believe in strength of

\begin{tabular}{lllll}
\hline & Frequency & Percent & Valid Percent & Total Percent \\
\hline IMAGE & 68 & 7,4 & 7,4 & 7,4 \\
IDEAS & 120 & 13,1 & 13,1 & 20,5 \\
TECHNOLOGY & 107 & 11,7 & 11,7 & 32,2 \\
RESEARCH & 52 & 5,7 & 5,7 & 37,8 \\
WORK & 166 & 18,1 & 18,1 & 55,9 \\
MONEY & 213 & 23,2 & 23,2 & 79,2 \\
CONTACTS & 74 & 8,1 & 8,1 & 87,2 \\
OTHER & 117 & 12,8 & 12,8 & 100,0 \\
TOTAL & 917 & 100,0 & 100,0 & \\
\hline \hline
\end{tabular}


APPENDIX 11: Frequencies aboutthe parts of which a fraction is composed

\begin{tabular}{llllll}
\hline \hline A fraction is composed of & & & & \\
\hline & Frequency & Percent & Valid Percent & Total Percent \\
\hline Inquiries and decimal & 79 & 8,6 & 8,6 & 8,6 \\
$\begin{array}{l}\text { Numerator } \\
\text { denominator }\end{array}$ & and776 & 84,6 & 84,6 & 93,2 \\
3 parts & 32 & 3,5 & 3,5 & 96,7 \\
4 parts & 30 & 3,3 & 3,3 & 100,0 \\
Total & 917 & 100,0 & 100,0 & \\
\hline \hline
\end{tabular}

APPENDIX 12: Frequencies aboutdegree of satisfaction with the school's laboratory infrastructure. On the scale from 1 to 5 (with the maximum of 5) how satisfied are you with your school's laboratory?

\begin{tabular}{lllll}
\hline & Frequency & Percent & Valid Percent & Total Percent \\
\hline 1 & 103 & 11,2 & 11,2 & 11,2 \\
2 & 170 & 18,5 & 18,5 & 29,8 \\
3 & 242 & 26,4 & 26,4 & 56,2 \\
4 & 244 & 26,6 & 26,6 & 82,8 \\
5 & 158 & 17,2 & 17,2 & 100,0 \\
Total & 917 & 100,0 & 100,0 & \\
\hline \hline
\end{tabular}

